\title{
Monoklonális antitestek és egyéb biológiai terápiák a COVID-19 kezelésére
}

\author{
Kacskovics Imre \\ Eötvös Loránd Tudományegyetem, Természettudományi Kar, Budapest, Magyarország
}

Beérkezett: 2021. július 1.; Elfogadva: 2021. július 19.

\begin{abstract}
Összefoglalás
A SARS-CoV-2 koronavírus által kiváltott pandémia az elmúlt mintegy 100 év legsúlyosabb közegészségügyi, gazdasági és társadalmi válságát okozza. Az emberiség soha nem látott tudással, példa nélküli sebességgel állította elő azokat a hatékony védőoltásokat, amelyek a megfeleló átoltottság mellett kontrollálhatják a COVID-19-járványt.

A SARS-CoV-2 fertőzéssel az emberiségnek meg kell tanulnia együtt élni, és mivel a vakcinák nem mindenkinek adhatók, vagy nem mindenkiben váltanak ki immunvédelmet, szükséges a jelenleginél hatékonyabb COVID-19-specifikus terápiák kifejlesztése. Több COVID-19 kezelésére kifejlesztett gyógyszerhatóanyagot is sikerrel tesztelnek, közülük is kiemelkednek a monoklonális antitestek, illetve más biológiai terápiák. Ezek egyfelól olyan gyógyszerek, amelyek a betegség korai fázisában semlegesítik a vírust, azaz megakadályozzák, hogy a sejteket megfertőzze, míg mások a már kialakult súlyos megbetegedésben csökkenthetik a gyulladás mértékét. Biologikumok közé tartozik a SARS-CoV-2-t semlegesítő hACE2-Fc fúziós fehérje is, amely a neutralizáló monoklonális antitestek hatásához hasonlítható; elónye, hogy minden mutáns ellen hatékony lehet.

Virológusok, járványügyi szakemberek szerint fel kell készülnünk arra, hogy a jelenlegihez hasonló járványok rendszeressé válnak. Ökológiai okok miatt egyre nő az állati eredetú kórokozók adaptálódása az emberhez, de nem zárhatók ki az ún. laborszökevény vírusok, ső́t a bioterrorizmus veszélye sem. Mindezek hatékony kezelésére erősítenünk kell a hazai biotechnológiai kapacitásokat. A hatóanyagfejlesztésben a már kialakult hazai egyetemi-kutatóintézeti-ipari együttmúködésekre számíthatunk, a gyártás során pedig a hazai korszerú biotechnológiai, gyógyszeripari kapacitásra, amelyek növelhetik az önellátásból származó biztonságot.
\end{abstract}

Kulcsszavak: COVID-19, koronavírus, terápiás monoklonális antitestek, Fc-fúziós fehérjék, biologikumok

\section{Monoclonal antibodies and other biologics for treatment of COVID-19}

\author{
Imre Kacskovics
}

Faculty of Science, Eötvös Loránd University, Budapest, Hungary

\begin{abstract}
Summary
The SARS-CoV-2 coronavirus pandemic is causing the worst public health, economic and social crisis in the last 100 years. New and effective vaccines were developed and produced with the application of unprecedented know how and speed, which can control the COVID-19 epidemic with the right vaccination coverage.

Humanity needs to learn to live with the SARS-CoV-2 infection, and because vaccines cannot be given to everyone or cannot induce immune protection in all vaccinated individuals, it is necessary to develop more effective COVID19-specific therapies than those presently available. Several drugs developed for the treatment of COVID-19 have been successfully tested, including monoclonal antibodies and other biological therapies. These are, on the one hand, drugs that neutralize the virus in the early stages of the disease, that is, it prevents it from infecting the cells, while others can reduce the rate of inflammation in a severe disease status. This review article provides an update about the current status of monoclonal antibodies that have been developed to treat COVID-19.

In early 2020 Eotvos Lorand University, Pecs University, Gedeon Richter Plc and ImmunoGenes Ltd formed a consortium to develop a molecular trap, the human ACE2-Fc fusion protein that binds to the spike protein of SARS$\mathrm{CoV}-2$ and inhibits its binding to the ACE2 receptors on the cell surfaces. We successfully produced this recombinant
\end{abstract}


protein and proved that it neutralizes this virus using VERO E6 cells and protects animals (Syrian hamster) from serious disease when administered before infection. We have also shown that it has a long half-life due to its ( $\operatorname{IgG})$ Fc-region component. Based on these proof of concept data, we created mutant versions of this drug candidate that do not have catabolic activity for angiotensin II and thus would not influence blood pressure. This is important since this drug should be administered in log-fold higher concentrations than ACE2 receptors in the body in order to efficiently neutralize the virus. The virus neutralization capacity of these new versions remained intact based on in vitro virus neutralization tests. We believe that after successful animal experiments, these drug candidates can be efficiently used in COVID-19 therapy in mild or moderate disease status. As compared to the COVID-19 specific monoclonal antibodies, we believe that these recombinant, mutant hACE2-Fc drugs can be more effective than the mAbs as they effectively bind and neutralize the new variants of SARS-CoV-2 (if they are able to bind the endogenous ACE2 receptor)

According to virologists and epidemiologists, we need to be prepared for epidemics like the current one becoming more regular. Due to ecological reasons, the adaptation of animal pathogens to humans is increasing, but there are threats due to lab leak viruses and even bioterrorism. To deal with all this effectively, we need to strengthen domestic biotechnology capacities. In the development of drug substances, we can count on the already established Hungarian university-research institute-industry collaborations, which can increase the safety resulting from self-sufficiency.

Keywords: COVID-19, coronavirus, therapeutic monoclonal antibodies, Fc fusion proteins, biologics

\section{Bevezetó}

A 2019-es koronavírus betegséget (COVID-19), a súlyos akut légzőszervi szindrómát okozó koronavírus 2 (SARS-CoV-2) egy olyan kórokozó, amely az embereket korábban sosem támadta, és mivel (i) senki sem volt védett ellene, (ii) nagy fertőzóképességgel rendelkezik, (iii) lappangási ideje relatív hosszú, valamint (iv) a legtöbb esetben tünetmentes fertőzést okoz, hamarosan világjárványt okozott. A SARS-CoV-2 a Coronaviridae család Béta-koronavírus nemzetségbe tartozik. 2002 óta három, ebbe a nemzetségbe tartozó, állatról emberre terjedő (zoonotikus) patogén koronavírust azonosítottak. A súlyos akut légzőszervi szindrómát okozó koronavírus (SARS-CoV) a 2002-2003 években mintegy 8000 embert fertőzött meg és a betegséggel összefüggő halálozási arány csaknem 10\%-os volt. A 2012-ben, 2015ben és 2018-ban felbukkant MERS-CoV (közel-keleti súlyos akut légzőszervi szindrómát okozó koronavírus) eddig összesen körülbelül 2500 embert fertőzött meg, de halálozási aránya mintegy $35 \%$ (!) volt. A SARS-CoV és a MERS-CoV alacsony fertözőképességüek, de magas halálozással járó koronavirusok.

A SARS-CoV-2 fertözóképessége magas, a fertözöttek mintegy 80\%-a tünetmentes, vagy enyhe tüneteket mutat; 15-20\%-uk azonban súlyos légzöszervi elégtelenséget mutat, illetve légzés-keringés összeomlás alakul ki, amely halálos is lehet. Eddig a világon igazoltan több mint 180 millió ember fertőződött meg a COVID-19-ben, és közülük csaknem 4 millióan hunytak el (ez a fertőzöttek mintegy 2\%-a, de ez az arány még nem kellően megalapozott, hiányoznak a globális mutatók - azaz a halálozást nagymértékben befolyásoló egészségügyi ellátás jelentős különbséget mutat az egyes országok/régiók vonatkozásában, illetve egyre fertőzőbb és veszélyesebb mutánsok keletkeznek, amelyek módosíthatják ezt az arányt).

A SARS-CoV-2 burkán található ún. tüskefehérje (S-protein) receptor kötő domén (RBD) nagy affinitással kötődik a vérnyomás szabályozásban jelentős angioten- zin konvertáló enzim 2 receptorhoz (ACE2) (Wrapp et al. 2020). Az ACE2 receptort számos sejttípus kifejezi, például 1-es és 2-es típusú légzőhámsejtek, vékonybélhámsejtek, vesehámsejtek, az artériák és vénák endotélsejtjei, az artiolák simaizomsejtjei. A SARS-CoV-2 RBD ACE2 kötődését követően a tüskefehérjében térszerkezeti változás alakul ki, és egy sejtfelszíni szerinproteáz (TMPRSS2) hatására annak egy része (S1 domén) lehasad. Ennek révén a tüskefehérje S2 doménje hatékonyan fuzionál a sejtmembránnal, majd a vírus a sejtbe jut (Dai és Gao 2021). A sejtbe került vírus ezt követően megsokszorozódik, majd az így létrejött vírusok kiszabadulnak a sejtekból és a szomszédos sejteket is megfertőzik, illetve a véráram révén a sokféle szövetben lévő ACE2-t kifejező sejteket megfertőzik és megbetegítik. Ennek révén a beteg sok szervében alakulnak ki kóros gyulladások, súlyos zavarok.

A SARS-CoV-2 főként a fertőzött személy kilégzéséból származó mikrocseppekkel terjed. A belélegzett mikrocseppekben lévő vírus a tüdő bronchiolusaiban és alveolusaiban lévő hámsejteket fertőzi meg elsőként, amelyekben autofágiát, sejtleválást, valamint az ACE2 kifejeződésének gátlását okozza. Ennek hatására az angiotenzin II peptid az angiotenzin II receptor 1 típusához tud csak kapcsolódni (azaz nem az ACE2 receptorhoz, ami elbontaná), és akut tüdősérülést okoz. A vírusfertőzött sejtek általában I és III típusú interferonokat termelnek, amelyek antivirális hatásúak, de a SARS-CoV-2 koronavírus valamiképpen gátolja ezt a mechanizmust. Mi több, sokkal aktívabban indukálja a gyulladást keltő citokinek/kemokinek - IL-1B, IL-6, TNF és IL1RA termelését (García 2020).

A következő fázis sorsfordító. A veleszületett immunrendszer aktiválódásának hatására vagy a védő hatású adaptív immunválasz alakul ki és a beteg meggyógyul, vagy az immunrendszer túlzott aktivitása miatt egy fokozott gyulladás veszi kezdetét, ami akár halálos is lehet.

$\mathrm{Az}$ adaptív immunválasz hatására vírust semlegesítő ellenanyagok keletkeznek, amelyek a tüskefehérjéhez kö- 
tődve meggátolják, hogy a vírus sejteket fertőzzön. A tünetek megjelenését követő mintegy 7 nap múlva lehet $\operatorname{IgM}$, majd további egy hét múlva IgG és IgA izotípusú antitesteket detektálni a betegek többségében. Bár a nyálkahártya felszínére zömében az IgA antitestek szekretálódnak, és védik a koronavírus-fertőzéstoól például az orr-garatüreget, az alsóbb légutakban - ideértve a tüdó alveolusait is, amelyekben az ACE2-t kifejezöléghámsejtek találhatók, és testszerte - az IgG-t tartjuk a legfontosabbnak. SARS-CoV-2 tüskefehérjéhez kötődő IgG típusú antitestek a betegségből felgyógyultak vérében még 3-4 hónappal később is kimutathatók, bár mennyiségük folyamatosan csökken. Jelenleg nem lehet tudni, hogy az alacsonyabb antitest szint elegendő védettséget nyújt-e az újrafertőződéstől (Chvatal-Medina et al. 2021).

A védőoltások valamennyi típusa, egyéntôl függő mértékben, nagy valószínúséggel kiváltja a koronavírus tüskefehérjét felismerő, azaz semlegesítő ellenanyag-termelést. Az így kiváltott ellenanyagok nem minden esetben akadályozzák meg a fertőzést, de csaknem mindenkit megóvnak a súlyos megbetegedéstől, illetve elhalálozástól. A pandémia kezdete óta viszonylag kevés idő telt el, és emiatt nehéz megbecsülni, hogy mennyi ideig jelentenek védettséget ezek az antitestek, illetve szükséges lesze rendszeres védőoltásokkal fenntartani a hatékony immunválaszt. Természetesen az újabb és újabb koronavírus mutánsok esetén, különösen, ha azok tüskefehérjéje módosul, előfordulhat, hogy az eredeti vírustörzzsel szemben kiváltott antitestek kevésbé hatékonyak a semlegesítésben. Ezért is fontos ezek folyamatos monitorozása és szükség esetén újabb védőoltások kifejlesztése.
Az immunrendszer az antitestek termelésén túl, citotoxikus $\mathrm{T}$ sejteket is generál, amelyek a vírusfertőzött sejteket pusztítják el, és ezzel a vírus számát, a virémia veszélyét csökkentik. Megjegyzendő, hogy a harmadik generációs (mRNA, vektoralapúak), illetve az attenuált védőoltások (ilyenek nincsenek még forgalomban) kiváltják a citotoxikus T sejtek termelődését is.

Általában ezek az immunválasz reakciók akkor alakulnak ki teljes mértékben, ha a fertőzést betegség is kíséri. Sok fertőzöttben, aki nem lesz beteg, nem alakul ki megfelelő mértékú humorális (ellenanyag) és celluláris (citotoxikus) immunválasz. A lezajlott és megfelelő immunválasz során memóriasejtek termelődnek, amelyek egy esetleges újabb fertőzést napok alatt képesek kontrollálni. Ebben az esetben 2-4 nap alatt megjelennek a nagyon specifikus IgG és IgA típusú antitestek, illetve citotoxikus $\mathrm{T}$ sejtek, amelyek megakadályozzák a súlyos betegség kialakulását. A védőoltások ismétlése is hasonló hatású, azaz a memóriasejtek létrehozásával hosszú távú és magas szintû́ védettséget hoz létre az oltottak többségében.

Ha a szabályozott immun-mechanizmusok helyett egy túlfokozott immunválasz alakul ki, amelynek egyik tünete az ún. citokinvihar (pl. IL6, TNF, IL1B), akkor súlyos gyulladás keletkezik az érintett szövetben. Mivel a tüdő a vírusfertőzés behatolási pontja, és ezért elsődlegesen érintett szerv, a súlyos gyulladás első jeleként súlyos akut légzési distressz szindróma (ARDS) jön létre, amit szisztémás intravaszkuláris koaguláció követ (testszerte véralvadékok képződnek az erekben). Tekintettel arra, hogy a SARS-CoV-2 sokféle sejtet, szervet tud megfertőzni,
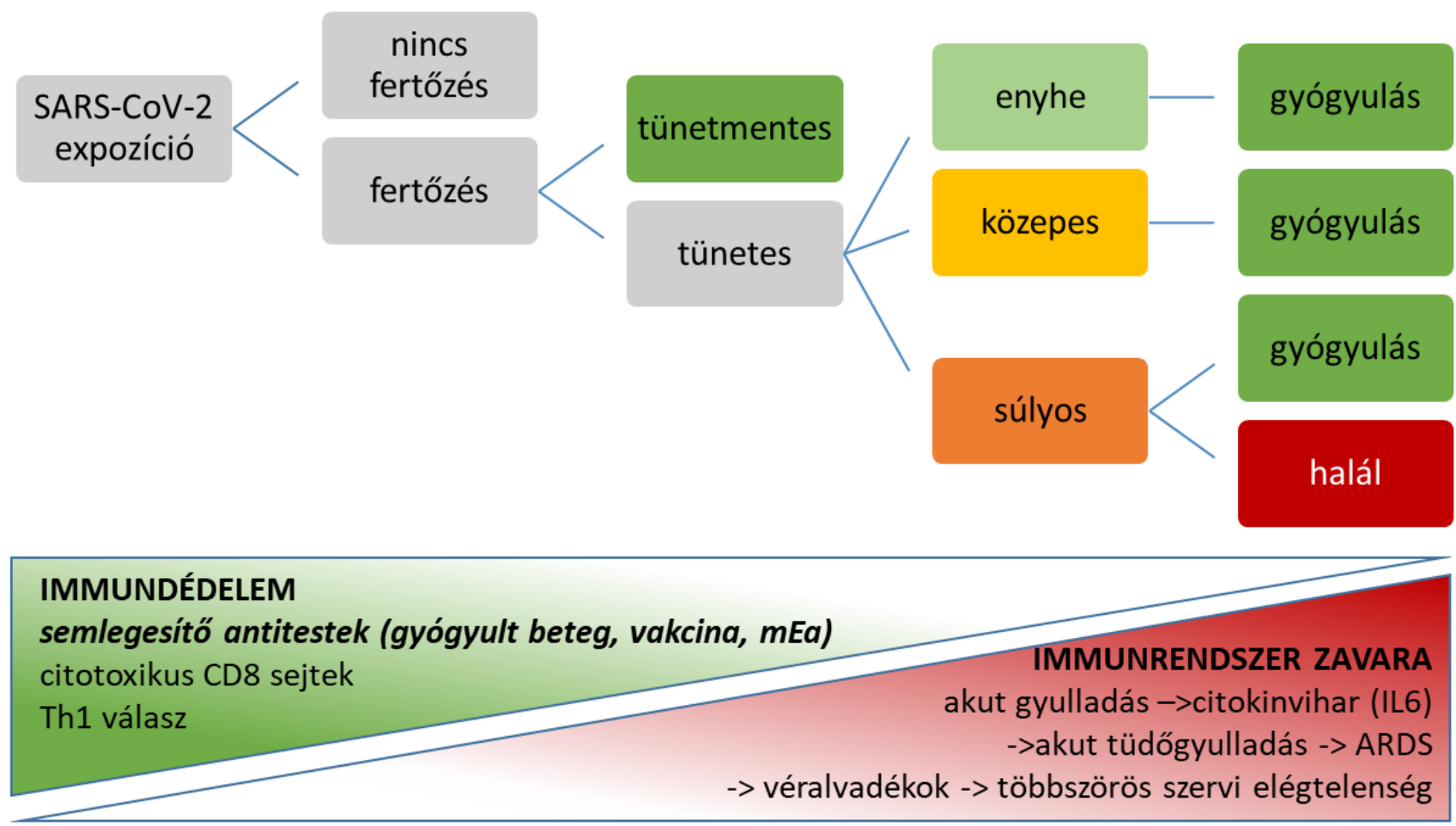

1. ábra | A COVID-19 kapcsán kialakuló immunválasz, gyulladás és klinikai spektrum (Garcia 2020 alapján) 
a klinikai tünetek is sokfélék lehetnek, okozhat tünetmentes fertőzést, enyhe, megfázásszerú tüneteket, közepesen súlyos és kritikusan súlyos (a fertőzöttek 15-20\%-a) megbetegedést. Az utóbbi általában kórházi, ún. intenzív betegellátó osztályon történő kezelést igényel, amely légzéstámogatást és más gyógyszeres terápiát (gyulladáscsökkentőket, pl. kortikoszteroidot, ill. a citokineket vagy receptoraikat gátló hatóanyagokat) nyújt a felgyógyulásig. Sajnos a betegek egy része nem reagál a jelenlegi kezelésekre és a betegségben elhalálozik (1. ábra) (Garcia 2020).

\section{Védőoltások a COVID-19 elleni nyájimmunitás elérésére}

A COVID-19 elleni páratlan sebességgel kifejlesztett és kiváló hatékonyságot mutató védőoltások a 21 . század kiemelkedő szintű biológiai ismereteinek és a biotechnológia fejlődésének valódi diadalát jelentik. A védőoltások által várva várt nyájimmunitás kialakítása, és vele együtt a múltban megszokott életünk visszatérése azonban nem lesz egyszerű folyamat. Bár a nyájimmunitás elérése reális elvárás a hatékony védőoltásoktól, annak elérése csak akkor lehetséges, ha a lakosság oltási hajlandósága is magas. Mindazonáltal, még teljes átoltottság esetén is lesznek olyan egészséges emberek, akiknek a szervezetében nem alakul ki immunvédelem. Emellett, az egyéb betegségek vonatkozásában sikeres terápiák hatására, az elmúlt évtizedekben jelentősen megnőtt az immunkomprimált betegek száma. Ebbe a csoportba tartoznak a veleszületett immunhiánnyal születettek, a citosztatikumokkal kezelt daganatos betegek, a csontvelő-, illetve szervátültetettek, a krónikus gyulladás ( $\mathrm{pl}$. rheumatoid arthritis, Crohn-betegség) miatt immunszuppresszív kezelésben részesültek (pl. kortikoszteroidok, metotrexát, gyulladásgátló biologikumok) és a HIV/AIDS-betegek. Egyelőre nem tudjuk, hogy a védőoltások hatására milyen szintű immunvédelem alakul ki bennük.

A tartós nyájimmunitás fenntartását az is nehezítheti, hogy az eddigi koronavírusok ellen viszonylag rövid életû́ védettség alakul ki, és nem tudhatjuk, hogy a SARSCoV-2 ellen kialakuló immunválasz mennyi ideig véd. Ráadásul új és veszélyes SARS-CoV-2 mutánsok alakulnak ki, amelyekkel szemben a védőoltások csökkent védelmet nyújthatnak. A SARS-CoV-2 vírus belátható időn belül nem fog eltûnni, meg kell tanulnunk együtt élni vele. A védőoltásokkal kiváltott nyájimmunitás szerepe sokkal inkább az lehet, hogy jelentősen csökkenjen a fertőzés gyakorisága, a fertőzési láncok kialakulása és terjedése (elemi reprodukciós ráta vagy $\mathrm{R}_{0}$ érték csökkenése). Mindez nemcsak az egészséges lakosokat, de a betegség kapcsán veszélyeztetettebb immunkomprimáltakat is védi, vagyis összességében csökkenti a súlyos betegek számát és a halálozást (és ezzel együtt az egészségügyre nehezedő nyomást, ami más típusú betegek ellátását is veszélyezteti).

\section{Passzív immunterápia SARS-CoV-2 specifikus antitestekkel}

\section{Konvaleszcens plazma terápia}

A COVID-19 betegség során, valamint védőoltások eredményeként a vérben is jól detektálható, a vírus tüskefehérjéhez kötődő és a vírust semlegesíteni képes antitestek termelődnek. A fertőzés vagy védőoltás hatására a szervezet sokféle B-limfocitája aktiválódik, és válik ellenanyag-termelő plazmasejtté, aminek eredményeképpen az antigén különböző epitópjához kapcsolódó sokféle ellenanyag termelődik a szervezetben (poliklonális immunválasz). Ezek közül lesznek olyanok, amelyek a tüskefehérje RBD-hez kapcsolódva megakadályozzák a fertőzést (neutralizáló antitestek), de olyanok is, amelyek a tüskefehérje egyéb régióját kötik és kevésbé képesek semlegesíteni a vírusfertőzést. A semlegesítő és a tüskefehérje-specifikus, de nem semlegesítő ellenanyagok aránya, minősége egyedi változást mutat, azaz minden emberben eltérő minőségű a poliklonális ellenanyagok összetétele és hatékonysága a vírus semlegesítésére. A koronavírus tüskefehérje-specifikus antitestek mennyiségi és minőségi elemzésére az ún. ELISA módszert alkalmazzák, de a vírus neutralizáló képességének elemzésére az ennél lényegesen bonyolultabb in vitro vírus neutralizációs assay alkalmas.

Ennek megfelelően már a COVID-19 első időszakában jelentős erőfeszítések történtek a COVID-19 betegek gyógyítására, a már felgyógyult és magas vírusspecifikus antitestet tartalmazó emberek vérsavójával (konvaleszcens plazma terápia; CPT) történő kezelésre. Jelentős előnye a passzív immunterápiának, hogy a kórokozóspecifikus ellenanyagok befecskendezését követő néhány óra alatt kifejtik védő hatásukat, ami több hónapig is fennmarad, illetve a kezelés megismételhető. Ezek a kezelések sokszor voltak eredményesek, de a megfelelő antitesttel (mennyiség és minőség) rendelkező donorok kiválasztása (a vírusneutralizációs elemzések egyedi szükségszerüsége), a vérplazma begyújtése és alkalmazása rendkívül komplex és alacsony hatékonyságú (2. ábra) (Torrente-López et al. 2021).

\section{Terápiás monoklonális ellenanyagok alkalmazása}

A monoklonális ellenanyagok ( $\mathrm{mEa}$ ) egyetlen B-limfocitából származnak, és fehérjeszinten, illetve antigénkötő képességükben teljesen egységesek, de más vonatkozásban eltérőek lehetnek (pl. a cukormintázatuk és az ehhez kapcsolatos immuneffektor funkciók változhatnak).

Kezdetben a terápiás monoklonális ellenanyagokat egerekben állították elő, majd biotechnológiai módszerrel átalakították, hogy az emberi ellenanyagokhoz hasonlítsanak, és ne legyenek idegenek az emberi szervezet számára, azaz ne váltsanak ki immunválaszt a betegben. Újabban olyan egereket, patkányokat, sőt nyulakat is al- 


\section{Passzív immunizálás - vírusneutralizálás}

\section{Konvaleszcens plazmaterápia (CPT)}

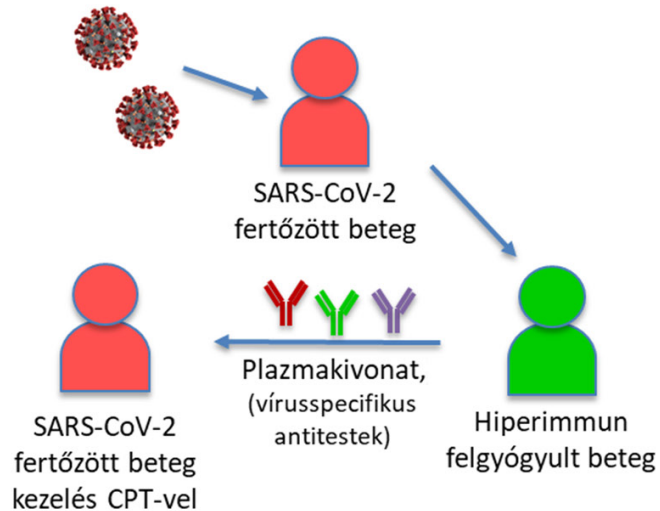

vírusspecifikus antitest (IgG) a SARS-CoV-2 tüskefehérjéhez kötődik és megakadályozza a fertőzést

kezelés CPT-vel

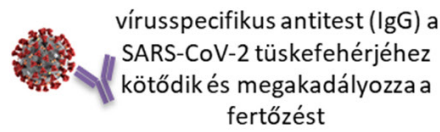

Biologikumok (mEa, ACE2-Fc)

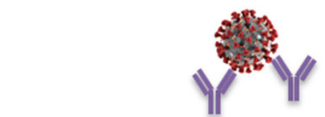

SARS-CoV-2 tüskefehérjét neutralizáló monoklonális ellenanyagok (mEa) 'koktélja'

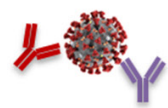

2. ábra

| Különböző passzív immunizálási stratégiák a SARS-CoV-2 semlegesítésére (Torrente-López et al. 2021 alapján)

kalmaznak erre a célra, amelyek génállományába az emberi ellenanyagokat kódoló génszakaszokat integrálják. Ennek eredményeként az ilyen „humanizált” génmódosított állatok emberi ellenanyagokat termelnek. Egy másik eljárás során a betegségból felépült emberek tüskefehérje RBD specifikus fehérvérsejtjeit (B-limfocitáit) izolálják, majd biotechnológiai eljárással állítanak elő monoklonális ellenanyagokat. Az ellenanyagok közül kiválasztják azt a néhányat, amelyek nagyon erősen kötődnek a tüskefehérje RBD régiójához, és megakadályozzák az RBD - ACE2 kapcsolódást, azaz koronavírus-neutralizáló hatásúak. A gyógyszeripari előállítás során génmódosított emlössejtek termelik a rekombináns ellenanyagokat, akár több ezer literes, ún. bioreaktorokban (gyógyszeripari minőségbiztonság betartásával). Az ilyen terápiás monoklonális ellenanyagok egységesen, mindig azonos minőségben és nagy mennyiségben készíthetők el és biztosítják a betegekben a vírus semlegesítését. Az ellenanyagok közül is az ún. IgGl-típusú mEa-k dominálják a terápiát, többek között azért, mert hosszú ideig, akár 3-5 hónapig is aktívak a szervezetben.

Monoklonális antitesteket több mint 20 éve használnak terápiás célra, elsősorban krónikus gyulladás, illetve tumor kezelésére. Mindeddig csupán egyetlen antivirális mEa-t alkalmaztak, a palivizumabot (Synagis ${ }^{\mathrm{TM}}$ ), amelyet 1998 óta használnak sikeresen a humán légúti óriássejtes vírus (RSV; respiratory syncitial vírus) semlegesítésére, magas egészségügyi kockázatú, például koraszülött vagy öröklött szívrendellenességgel született kisgyermekekben.

Ez az eljárás a konvaleszcens szérumterápia 21. századi alternatívája, és azzal szemben jelentős előnye, hogy a hatása standardizálható, az elkészültét követően pedig a hatóanyag korlátlan mennyiségben elóállítható. Fontos hangsúlyozni, hogy ez a gyógyszer nemcsak a már megfertőzött személyt képes megvédeni a súlyos betegségtől, de preventív célból is adható, és a szervezetbe kerülést követően már másnap véd, szemben a védőoltással, ami az első oltást követően minimum 2 héttel később kezd el hatni (általában a második oltás után egy-két héttel késóbb alakul ki a teljes mértékú immunvédelem, azaz az első oltást követő 5-6 hét múlva). Hátránya a költséges előállítása, de míg a védőoltással mindenkit szeretnénk védeni, addig a terápiás ellenanyagokkal a jóval kisebb számú, már megfertőződötteket kezelhetjük annak érdekében, hogy elkerüljék a jóval költségesebb kórházi kezelést, illetve a súlyos betegséget követő akár tartós életminőség-romlást, nem is beszélve a betegség halálos kockázatáról. Fontos, hogy az ilyen vírussemlegesítő ellenanyagokkal a magas kockázati csoportba sorolt fertőzötteket a betegség első fázisában kell kezelni. Később a súlyos gyulladás kialakulását követően nem várhatunk tőlük érdemi javulást. Bizonyos esetekben (pl. egyes immunkomprimált személyeknél, akikben a védőoltás nem vált ki megfelelő immunitást) pedig nem is lesz más lehetőség, mint a fertőződést követő gyorsan elvégzett antivirális ellenanyag-kezelés.

A COVID-19 pandémia során, a védőoltások fejlesztésével egy időben, megkezdődtek az ilyen típusú terápiás mEa-k előállításai is. Több cég fejleszt olyan gyógyszert, amely csak egyféle monoklonális ellenanyagot tartalmaz, de olyanok klinikai vizsgálatai is zajlanak, amelyek a tüskefehérje két különböző epitópjához kapcsolódó monoklonális ellenanyag 'koktélt' tartalmaznak 
a nagyobb hatékonyság érdekében (2. ábra) (TorrenteLópez et al. 2021).

$\mathrm{Az}$ első ilyen $\mathrm{mEa}$, amelynek híre bejárta a világot, a Regeneron által kifejlesztett REGN-COV2 volt, amit a cég által létrehozott humanizált egerekben kifejlesztett két koronavírust semlegesító monoklonális antitest (REGN10933 és REGN10987) 'koktélját' tartalmazza (ezzel kezelték sikeresen Trump elnököt is 2020 októberében).

Magyarország az elsők között volt, hogy COVID-19 terápiás monoklonális antitestet alkalmazzon, így az ELi Lilly által gyártott bamlanivimabot (tüskefehérjéhez kötődik és megakadályozza a tüskefehérje - ACE2 kapcsolódást) kezdték el alkalmazni 2021 januárjától az enyhe és középsúlyos állapotban lévő COVID-19 betegekben. A jelenleg is folyó klinikai vizsgálatok szerint az újabb mutánsok ellen önmagában kevésbé hatékony, viszont a szintén Eli Lilly által gyártott etesevimabbal (a tüskefehérje másik epitópja, amely szintén gátolja az ACE2 kötődést) kombinálva jó eredmények érhetők el. (Megjegyzendő, hogy mindkét antitestet COVID-19-ból felgyógyult személyek vírusspecifikus B sejtjeiból állították elő.)

\section{Citokingátló monoklonális antitestek a COVID-19 kezelésére}

A COVID-19 kórházi kezelése során jelenleg tesztelt mEa-k jelentôs része a koronavirus által kiváltott túlfokozott immunválasz szabályozására fókuszál. Jól ismert, hogy egyes COVID-19 betegekben az immunválasz aktivitása hirtelen nagy mennyiségű gyulladásos citokint eredményez ('citokinvihar'), amely életveszélyes szisztémás gyulladásos szindrómát okoz. A COVID-19 esetén, a gyulladásos citokinek közül az egyik legveszélyesebbnek tartott az interleukin-6 (IL-6), és ezért e citokinnek vagy e citokin receptorának (IL-6R) gátlására kifejlesztett mEa-ok (tocilizumab, sarilumab és siltuximab) tesztelése a pandémia kezdetétól zajlik (Torrente-López et al. 2021).

Az IL-6 szignalizáció gátlása mellett több más immunrendszert szabályozó mechanizmuson keresztül ható monoklonális ellenanyagot is tesztelnek: bevacizumab (anti-VEGF), eculizumab (anti-C5), emapalumab (antiinterferon-gamma), gimsilumab (anti-GM-CSF), mavrilimumab (anti-GM-CSF-R), itolizumab (anti-CD6), meplazumab (anti-CDl47), nivolumab (anti-PDI), pembrolizumab (anti-PDl) (Torrente-López et al. 2021).

Fontos, hogy ezeket a gyógyszereket évek óta sikerrel alkalmazzák a krónikus gyulladás, például a rheumatoid arthritis kezelésére. A már más betegségekre engedélyezett gyógyszerek újabb terápiás célra történő alkalmazását gyógyszer újrapozicionálásnak nevezik, és terápiás bevezetésük például a COVID-19-ben lényegesen rövidebb idő alatt megtörténhet, mint egy új hatóanyagú gyógyszeré. A gyulladást csökkentő monoklonális ellenanyagok COVID-19 kezelésének hatékonyságát jelenleg nagyszámú klinikai vizsgálatban tesztelik, de a végső konklúzió levonására még várni kell.

\section{Passzív immunterápia az ACE2-Fc fúziós fehérjével - magyar fejlesztésú hatóanyag a koronavírus ellen}

A hazai konzorciális (ELTE - PTE - Richter Gedeon Nyrt. - ImmunoGenes Kft.) fejlesztés során egy mEa hatásához hasonló, a SARS-CoV-2-vírus semlegesítésére alkalmas, fehérjetípusú gyógyszert (biologikum) fejlesztünk. A két részből álló fúziós fehérje egyik eleme a vírust a sejtekbe vezetó receptor, az angiotenzin-konvertáló enzim 2 (ACE2) szintetikusan elóállított része, amely a kórokozónak ahhoz a részéhez ( $S$-fehérjéje) kapcsolódik, amelyen keresztül az a sejtekbe hatol. Ha nagy mennyiségben juttatjuk a szervezetbe ezt a hatóanyagot, akkor a vírus az emberi sejtek receptorai helyett a fúziós fehérjéhez kötődik, mintegy molekuláris csapdaként viselkedik (2. és 3. ábra). A másik komponense az IgG stabilitásáért felelős, ún. Fc-régió. A fejlesztés alapötletét 2020. február elején, a járvány kirobbanásakor vetették fel (Kruse 2020).

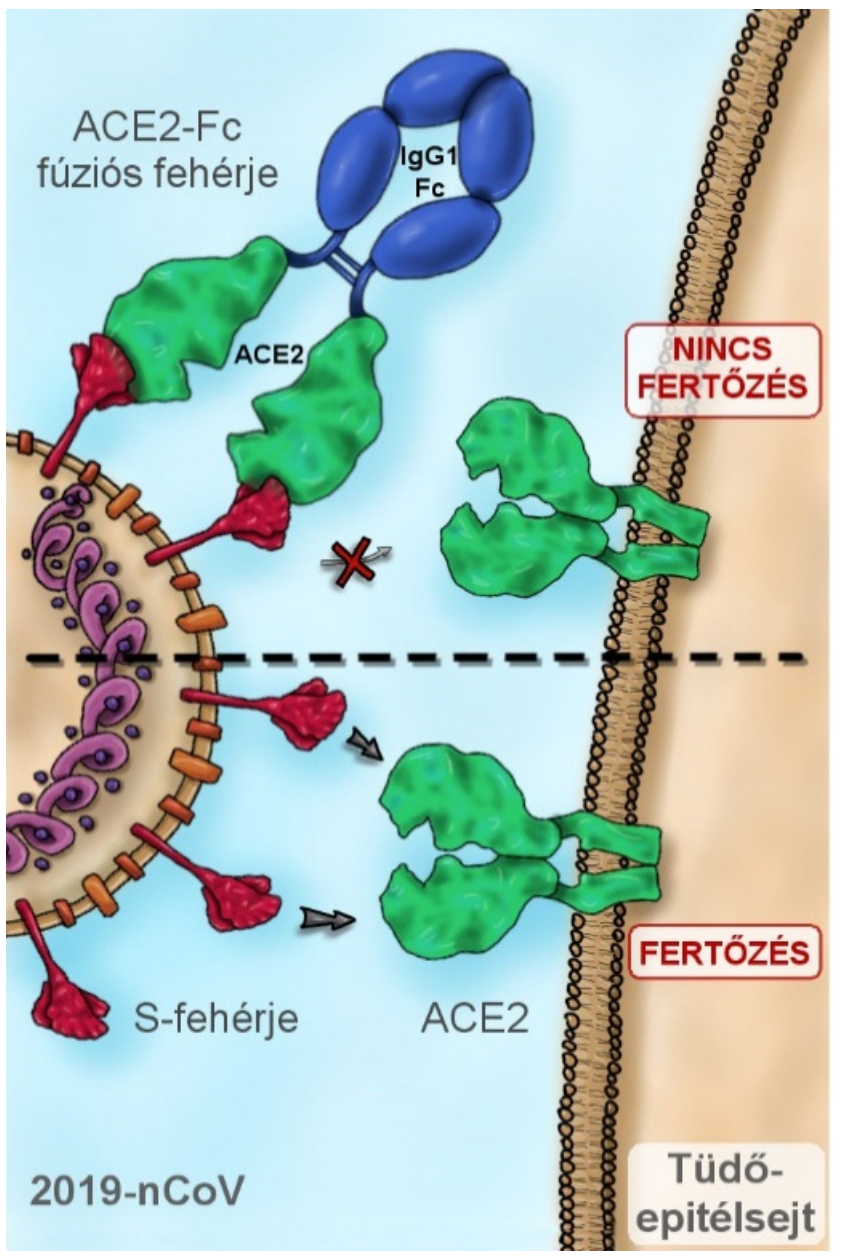

3. ábra $\quad$ Az ACE2-Fc fúziós fehérje hatásmechanizmusa a SARS-CoV2 koronavírus által kiváltott COVID-19 megelőzése és kezelése kapcsán (Marx Anita, ELTE TTK Immunológiai Tanszék ábrája) 
A Richter Gedeon Biotechnológiai Üzletág szakértői sikeresen elő́llították a hatóanyagot, és analitikai vizsgálatokkal igazolták, hogy nagyon erősen (nanomoláris affinitással) kapcsolódik a koronavírus tüskefehérjéhez (S-fehérje). Ez a kötéserősség hasonló mértékű a monoklonális antitestekéhez, azaz bízhatunk benne, hogy azokhoz hasonló hatékonysággal neutralizálja a vírust. Az mEa-val összehasonlítva egy fontos elönye az ACE2Fc biologikumnak, hogy gyakorlatilag minden patogén vírusmutáns ellen véd, hiszen amennyiben a vírus úgy mutálódik, hogy nem képes a hatóanyaghoz erősen kapcsolódni, akkor a sejtek felszínén lévő ACE2 receptorhoz sem fog tudni kötődni, így ártalmatlanná válik.

Az elmúlt hónapokban a Pécsi Tudományegyetem Szentágothai János Kutatóközpont kutatóinak sikerült igazolni, hogy az ACE2-Fc hatóanyagunk sejtkultúrában gátolja a SARS-CoV-2 fertőzőképességét (vírusneutralizációs teszt), valamint az első állatkísérletekben a kísérleti állatok megbetegedését is megakadályozta. Az ELTE és az ImmunoGenes kutatói igazolták, hogy a biologikum hosszú ideig kimutatható a kísérleti állatok szervezetében, illetve sikerült olyan génmódosított egereket elóállítani, amelyek a humán ACE2 receptort fejezik ki, azaz alkalmasak lehetnek a hatóanyag széles körű tesztelésére. Ezenkívül olyan variánsokat is fejlesztünk, amelyek az eredeti molekula mutációs változatai, és azt várjuk tőlük, hogy a vírusgátlást még hatékonyabbá tegyék. A következő időszakban még több állatkísérletet fogunk elvégezni, mielőtt a klinikai vizsgálatokat megkezdhetnénk.

Hangsúlyozandó, hogy a projektben zajló biotechnológiai kutatás-fejlesztés egyetemi és ipari résztvevők szoros együttmúködésével valósul meg. Az ELTE és PTE mint egyetemi, és a Richter Gedeon és az ImmunoGenes mint ipari partnerek együttesen biztositják, hogy jelen esetben nem csupán egy kutatólaboratóriumi kisérletről van szó. A Richter Gedeon szakértöinek köszönbetöen a kiindulástól kezdve a gyógyszeripari minöségbiztositás és eltökélt piacra vitelhez szükséges gyógyszer forgalomba hozatali feltételek figyelembevételének szemlélete jellemzi a munkát. Ennek kapcsán, hazai és külföldi szakértők bevonásával megkezdődött az egyeztetés az Európai Gyógyszerügynökséggel (EMA). Reméljük, hogy lesz magyar fejlesztésû biologikumunk, ami hatékonyan járul majd hozzá a COVID-19 elleni védekezéséhez.

\section{Konklúzió}

A monoklonális ellenanyagok előállítása költséges és időigényes folyamat, és eddig leginkább a krónikus gyulladás és tumor terápiájára alkalmazták ezeket a hatóanyagokat. Az elmúlt időszakban számos fejlesztés irányult a kórokozókkal szemben történő alkalmazásra, illetve a COVID-19 új lendületet adott ezeknek a fejlesztéseknek. A pandémia megjelenése óta számos SARS-CoV-2 tüskefehérjéhez kötődő neutralizáló ellenanyagot fejlesztettek, és néhányukat sikerrel alkalmazzák enyhe, középsúlyos COVID-19 betegekben. A súlyos gyulladás gátlására alkalmazott, többségében citokin szignalizációt gátló monoklonális ellenanyagok klinikai vizsgálatainak eredményei egyelőre ellentmondásosak, hatékonyságukat nem lehetett egyértelmúen igazolni.

A hazai biotechnológiai fejlesztések eljutottak arra a pontra, hogy akadémiai-ipari összefogással olyan biologikumot fejlesszenek, amely nemzetközi szinten is versenytársa lehet a globális cégeknek, amelyek nemzetközi szinten is egyetemek és kisebb cégek fejlesztéseit hasznosítják. A már meglévő hazai biotechnológiai kompetenciát nemcsak megtartani szükséges, de tovább erösíteni is érdemes.

\section{Irodalomjegyzék}

Chvatal-Medina, M., Mendez-Cortina, Y., Patiño, P. J., Velilla, P. A., \& Rugeles, M. T. (2021) Antibody Responses in COVID-19: A Review. Front Immunol., 15 Apr 2021, DOI: 10.3389/fimmu.2021.633184

Dai, L., \& Gao, G. F. (2021) Viral targets for vaccines against COVID-19. Nat Rev Immunol., Vol. 21. No. 2. pp. 73-82. DOI: 10.1038/s41577-020-00480-0

García, L. F. (2020) Immune Response, Inflammation, and the Clinical Spectrum of COVID-19. Front. Immunol., 16 June 2020, https://doi.org/10.3389/fimmu.2020.01441

Kruse, R. L. (2020) Therapeutic strategies in an outbreak scenario to treat the novel coronavirus originating in Wuhan, China. F1000Research 2020, 9:72, https://doi.org/10.12688/f1000research.22211.1

Torrente-López, A., Hermosilla, J., Navas, N., Cuadros-Rodríguez, L., Cabeza, J., \& Salmerón-Gercía, A. (2021) The relevance of monoclonal antibodies in the treatment of COVID-19. Vaccine, Vol. 9. No. 6. 557. https://doi.org/10.3390/vaccines 9060557

Wrapp, D., Wang, N., Corbett, S. K., Goldsmith, J. A., Hsieh, C.-L., Abiona, O., ... McLellan, J. S. (2020) Cryo-EM structure of the 2019-nCoV spike in the prefusion conformation. Science, Vol. 367. No. 6483. pp. 1260-1263; DOI: 10.1126/science.abb2507

A cikk a Creative Commons Attribution 4.0 International License (https://creativecommons.org/licenses/by/4.0/) feltételei szerint publikált Open Access közlemény, melynek szellemében a cikk bármilyen médiumban szabadon felhasználható, megosztható és újraközölhető, feltéve, hogy az eredeti szerző és a közlés helye, illetve a CC License linkje és az esetlegesen végrehajtott módosítások feltüntetésre kerülnek. (SID_1) 